\title{
PKM-KELOMPOK TANI ALAM SUBUR DI DESA NDUARIA KECAMATAN KELIMUTU KABUPATEN ENDE NUSA TENGGARA TIMUR
}

\author{
Yustina M.S.W. Pu'u' ${ }^{1)}$, Charly Mutiara ${ }^{2)}$, Yohanes Pande ${ }^{3)}$ \\ ${ }^{1,2)}$ Fakultas Pertanian, Universitas Flores \\ ${ }^{3)}$ Fakultas Hukum, Universitas Flores \\ E-mail: yus_puu@yahoo.com ${ }^{1)}$, charlyinter1988@gmail.com ${ }^{2)}$,pandejohanes@gmail.com ${ }^{3)}$
}

\begin{abstract}
Abstrak
Partners in this PKM is Alam Subur Farmers in Nduaria Village that has fifteen members. Based on the results of a survey conducted, it is known that the problems faced by partners are lack of counseling and assistance to farmer groups in the use of inputs and fertilizers and pesticides, the price of chemical fertilizers and pesticides is very expensive and very complicated to obtain, farmers do not know how to make organic fertilizers and pesticides that use plants around the farmers' land, farmers do not know how to control pests and diseases in cabbage and mustard plants, the statutes and bylaws of the group are not legally strong, and group management is still weak.

The solution provided to overcome the problems of partners is to provide knowledge and skills to farmers in this group about the facilities and infrastructure used in aquaculture activities, the correct use of fertilizers and pesticides in aquaculture activities, making organic fertilizers and vegetable pesticides from plants around farmer's land, control of pests and diseases in cultivated plants and good group management by making a statute and bylaws.

Output targets to be achieved in PKM activities include a scientific article published through an ISSN journal, an article in print media, a video of PKM activity, and farmers can make organic fertilizer and pesticides from plants around their land. The methods that will be used in achieving the above objectives are counseling and training. The results achieved are $90 \%$ of farmers have understood and can make organic fertilizers and pesticides.
\end{abstract}

\section{Kata Kunci: Farmer group, fertilizer, pesticide, organic}

\section{PENDAHULUAN}

Kelompok tani alam subur adalah salah satu kelompok tani yang tergabung dalam Gapoktan di desa Nduaria Kecamatan Kelimutu Kabupaten Ende. Kelompok tani alam subur dalam usaha tani sayuran berperan sebagai distributor sayur untuk wilayah Flores pada khususnya dan Nusa Tenggara Timur pada umumnya. Produksi rata-rata per orang untuk kubis maupun sawi adalah 3.000 pohon dengan harga yang berbeda untuk musim hujan dijual 5.000 per pohon dan musim kemarau dijual 10.000 per pohon. Keberadaan dan keberlanjutan kelompok tani alam subur tidak terlepas juga dari dukungan banyak pihak salah satunya pemerintah daerah dalam hal bantuan yang diberikan kepada kelompok, dimana sejak terbentuk dari 2004 sampai saat ini dukungan yang diberikan antara lain infrastruktur, pupuk organik "Testagro" sebanyak 30 ton pada tahun 2012- 2013 dan peralatan seperti handtraktor, alat semprot, benih (jagung, brokoli, kopi, cengkeh) hingga saat ini dan dimanfaatkan oleh semua anggota kelompok. Ketersediaan peralatan yang dimiliki oleh kelompok hingga saat ini adalah mesin pompa air, mesin potong rumput, dan mesin semprot (mix blower). Bantuan yang diberikan oleh Pihak Pemerintah dalam hal ini Dinas Pertanian Kabupaten Ende hanya sebatas pada pemberian bantuan baik berupa saprodi maupun pupuk dan pestisida tetapi tidak ada penyuluhan tentang bagaimana cara menggunakannya seperti untuk benih maupun pupuk. Hal ini menyebabkan saprodi maupun pupuk yang diberikan mubazir karena tidak digunakan oleh para petani dalam kelompok tani tersebut.

Keterbatasan informasi yang diberikan oleh Pemerintah melalui bantuan yang diterima oleh kelompok tani ini, menyebabkan kurangnya pengetahuan petani dalam hal pemanfaatan teknologi-teknologi pertanian seperti benih, pupuk maupun pestisida. Usaha tani merupakan satusatunya ujung tombak pembangunan Nasional yang mempunyai peranan penting. Kondisi yang dihadapi dalam usahatani kita dalam mengembangkan kegiatan produktif diantaranya adalah masalah transformasi dan informasi untuk petani pada kenyataannya sering menunjukkan susasana yang mencemaskan. Di satu pihak memang terdapat kenaikan produksi, tetapi di lain pihak tidak dapat dihindarkan akan terjadinya Berbagai permasalahan 
seperti terlemparnya tenaga kerja ke luar sektor pertanian yang tidak tertampung dan tanpa keahlian dan keterampilan, terjadi ledakan hama tanaman karena terganggunya keseimbangan lingkungan sebagai akibat kurangnya informasi mengenai hal tersebut, transformasi informasi harga karena belum adanya kemitraan, lemahnya tingkat teknologi dimana dalam pengembangan komoditas usaha tani diperlukan perbaikan di bidang teknologi seperti teknologi budidaya, teknologi penyiapan sarana produksi terutama pupuk dan obat-obatan (Fadholi, 1981).

Keterbatasan informasi dan transformasi tersebut menyebabkan permasalahan yang dihadapi oleh kelompok tani saat ini dalam 2 bulan terakhir adalah terjadinya ledakan hama dan penyakit pada tanaman kubis dan sawi yang disebabkan oleh Plutella xylostella L. dan bercak daun. Hal ini disebabkan karena, petani belum memiliki informasi serta keterampilan dalam hal tindakan pengendalian lainnya seperti pengendalian dengan pestisida organik yang dapat dimanfaatkan dari tanaman sekitar tanpa dibeli dengan biaya yang sangat mahal. Hasil penelitian yang dilakukan (Pu'u and Charly, 2018) menunjukkan bahwa jenis tanaman yang dapat digunakan sebagai pupuk organik dan pestisida nabati di Kecamatan Kelimutu antara lain Mimba (Azadirachta indica), Kirinyuh (Chromolaena odorata), Gamal (Gliricidia sepium), Sirsak (Annona muricata), Srikaya (Annona squamosa), Legundi (Vitex trifolli Linn.), dan Serai Wangi (Cymbopogon nardus), Cengkeh (Syzygium aromaticum), Pepaya (Carica papaya L), Cabai Merah (Capsicum annuum), Jahe (Zingiber officinale), dan Kelor (Moringa oleifera) dengan indeks keragaman sedang.

Tujuan dari Program Kemitraan Masyarakat (PKM) ini adalah melakukan pembinaan dan pemberdayaan masyarakat dalam pengelolaan budidaya tanaman melalui pemanfaatan sarana dan prasarana produksi berupa pupuk organik dan pestisida nabati, upaya-upaya pengendalian terhadap hama dan penyakit tanaman serta manajemen kelompok tani yang diatur dalam AD dan ART serta peningkatan keterampilan dalam proses pembuatan pupuk organik dan pestisida nabati dari tanaman lokal.

\section{METODE KEGIATAN}

Berdasarkan permasalahan yang dihadapi oleh Mitra program PKM ini dilaksanakan dengan tahapan sebagai berikut :
1. Penyuluhan

Hal-hal yang disampaikan kepada Mitra dalam kegiatan penyuluhan ini adalah penggunaan saprodi pertanian dalam budidaya tanaman sayuran dan buah, pemanfaatan pupuk dan pestisida dalam budidaya tanaman mulai dari pengertian pupuk dan pestisida, jenis pupuk dan pestisida, dan cara penggunaan pupuk dan pestisida, jenis pupuk dan pestisida non kimia sehingga ketergantungan terhadap pupuk anorganik berkurang, pengenalan hama dan penyakit pada tanaman serta teknik pengendalian secara terpadu, dan manajemen kelompok tani. Kegiatan ini dilakukan sebanyak 5 kali selama 2 bulan dan setiap pertemuan selama \pm 5 jam/pertemuan. Materi-materi ini disampaikan sebagai upaya dalam peningkatan pengetahuan anggota kelompok tani pada kegiatan budidaya tanaman yang dilakukan.

2. Pelatihan

Pelatihan dilaksanakan langsung di Kebun Mitra dan diikuti oleh 30 orang peserta yang berasal dari anggota kelompok dan petani yang kebunnya berdekatan. Jenis pelatihan yang dilakukan yaitu: penggunaan saprodi pertanian dalam budidaya tanaman sayuran dan buah, pembuatan pupuk organik dan pestisida nabati dari bahan dasar tanaman yang ada di sekitar petani dan cara aplikasi, pengenalan hama dan penyakit pada tanaman serta teknik pengendalian secara terpadu, dan pembuatan AD/ART. Pelaksanaan pelatihan dilakukan sebanyak 5 kali selama 2 bulan dan setiap kegiatan pelatihan $\pm 5-8 \mathrm{jam} /$ pelatihan.

3. Evaluasi Program

Memantau secara langsung proses pelaksanaan pelatihan dan hasil (cara membuat dan aplikasi). Evaluasi dilakukan terhadap pemahaman petani dalam menggunakan saprodi, melakukan tindakan pengendalian terhadap hama dan penyakit yang menyerang tanaman budidaya, cara membuat pupuk dan pestisida dari bahan tanaman sekitar serta cara menyusun anggaran dasar dan anggaran rumah tangga kelompok melalui kegiatan pre-post test.

4. Pendampingan, Pembinaan dan Monitoring

Kegiatan pendampingan dilakukan terhadap keberlanjutan dalam pembuatan pupuk organik 
serta pestisida nabati dan penanganan hama dan penyakit secara terpadu pada lahan demplot yang dibuat. Setelah dilakukan pendidikan dan penyuluhan, pelatihan dan demonstrasi, serta demplot percontohan, selanjutnya akan dilakukan pembinaan secara berkelanjutan di lapangan dan memonitoring untuk mengetahui keberhasilan dari kelompok. Hasil monitoring dijadikan sebagai bahan evaluasi untuk kemudian ditindaklanjuti, yakni dengan memantapkan teknologi yang masih dianggap kurang.

5. Partisipasi Mitra

Partisipasi mitra yaitu menyediakan peserta sebanyak 30 orang dan menyediakan tempat penyuluhan dan pelatihan serta alat dan bahan yang dibutuhkan dalam pembuatan pupuk dan pestisida organik dari tanaman sekitar serta pengendalian hama dan penyakit tanaman.

\section{HASIL DAN PEMBAHASAN}

Pelaksanaan kegiatan Program Kemitraan Masyarakat (PKM) di kelompok tani Alam Subur desa Nduaria Kecamatan Detusoko Kabupaten Ende yang dilakukan adalah penyuluhan, pelatihan dan evaluasi kegiatan serta pendampingan.

\section{A. Penyuluhan}

Pelaksanaan kegiatan pembedayaan masyarakat melalui kegiatan penyuluhan yang telah dilakukan yaitu penggunaan saprodi pertanian dalam budidaya tanaman sayuran dan buah, pemanfaatan pupuk dan pestisida dalam budidaya tanaman, jenis pupuk dan pestisida non kimia, pengenalan hama dan penyakit tanaman serta teknik pengendalian secara terpadu dan manajemen kelompok tani. Penyuluhan ini dimaksudkan untuk memberikan informasi kepada petani dalam melakukan kegiatan budidaya baik yang berhubungan dengan saprodi maupun penanganan hama dan penyakit (Adriyani, 2006) serta pengelolaan kelompok tani yang benar sesuai AD/ART. Petani diberikan pengetahuan tersebut berdasarkan kebutuhan mereka dan permasalahan yang dihadapi. Kegiatan penyuluhan ini diikuti oleh 15 orang anggota kelompok tani dan 15 orang dari petani lain yang berdekatan kebunnya. Kegiatan penyuluhan dilakukan secara partisipatif sehingga setiap peserta diberikan kesempatan untuk menyatakan pendapat dan pengalaman dalam pelaksanaan kegiatan usaha taninya. Dari pendapat yang diberikan, dapat ditarik kesimpulan bagaimana aktivitas Pertanian para petani khususnya terkait Pertanian organik (Emiria and Purwandari, 2014).

\section{B. Pelatihan}

Pelatihan dilakukan secara langsung di kebun kelompok tani dan diikuti oleh semua anggota kelompok sebanyak \pm 15 -30 orang. Jenis pelatihan yang dilakukan meliputi:

1. Pelatihan tentang penggunaan saprodi pertanian dalam budidaya tanaman sayuran dan buah.

Pelatihan ini bertujuan agar semua anggota kelompok tani dapat menggunakan mesin pencacah dalam proses pembuatan pupuk organik. Pelatihan ini dimulai dengan pengenalan cara menggunakan mesin pencacah dan percobaan daun kirinyuh untuk dicacah.

2. Pelatihan pembuatan pupuk organik

Tahapan dalam pembuatan pupuk organik yang dilakukan yaitu persiapan alat dan bahan yang akan digunakan dan dilanjutkan dengan proses pembuatan pupuk yaitu: Mengumpulkan daun kirinyuh dan ditimbang sebanyak $20 \mathrm{~kg}$. Daun Kirinyu digunakan karena banyak ditemukan di daerah tersebut serta mempunyai kandungan hara yang lengkap sehingga dapat meningkatkan hasil tanaman (Marpaung, 2017). Daun kirinyuh kemudian dimasukkan dalam mesin pencacah secara perlahan sampai keluar hasil cacahannya dan dimasukkan dalam gentong ukuran 60 liter. Hasil cacahan daun kirinyuh kemudian dicampurkan dengan air sebanyak 10 liter atau 2/3 tinggi gentong, kemudian dimasukkan 6 sendok makan gula air dan 9 tutup botol bakteri pengurai EM4 untuk mempercepat proses penguraian (Islamiyati, 2014). Semua bahan tersebut kemudian diaduk rata, dan gentong ditutup rapat-rapat sehingga udara tidak bisa masuk ke dalam gentong dan disimpan di tempat teduh dan terhindar dari sinar matahari langsung selama 4 minggu. Setiap 2 minggu dibuka tutupannya kurang lebih 5 menit kemudian ditutup lagi. Setelah 6 minggu, dilakukan pengamatan pada pupuk. Ciri-ciri pupuk organik yang sudah siap digunakan adalah tidak berbusa, adanya bercak-bercak putih pada permukaan 
cairan. Cairan yang dihasilkan dari proses ini akan berwarna coklat kehiataman dengan bau/aroma khas. Pupuk yang sudah jadi kemudian diperas untuk dipisahkan cairan dan padatannya. Cairan kemudian disaring dan dimasukkan dalam jerigen sebagai pupuk organik cair. Ampas dari sisa pemerasan pupuk dibenamkan dan dicampurkan ke bedengan persemaian. Aplikasi pada tanaman dengan dosis 6 tutup botol dilarutkan dalam 151 air dan disemprotkan ke daun atau tanah sekitar tanaman.

3. Pelatihan Pembuatan Mikroorganisme Lokal (MOL) penganggti EM4

Tahapan dalam pembuatan MOL yang dilakukan yaitu persiapan alat dan bahan yang akan digunakan kemudian dilanjutkan dengan proses pembuatan. Bahan yang digunakan sangat berpengaruh Terhadap kualitas MOL yang dihasilkan (Palupi, 2015). Dalam kegiatan ini, pertama memasukkan daun kirinyuh, rumen sapi, kotoran ternak, tanah di daerah perakaran bambu, dan dedak ke dalam gentong lalu diaduk hingga merata. Kedua masukkan air gula sebagai pengganti air kelapa sebanyak 20 liter. Ketiga masukkan terasi sebanyak 50 gr kemudian larutkan gula ke dalam 5 liter air kemudian aduk hingga merata dan masukkan ke dalam gentong. Keempat tambahkan air sebanyak 10 liter yang bukan berasal dari PAM atau air hujan, lalu aduk lagi hingga merata, kemudian gentong ditutup jangan terlalu rapat supaya ada sirkulasi udara. Kelima adonan diaduk setiap hari sampai 14 hari, dan setelah itu MOL dapat digunakan dalam pembuatan pupuk ataupun langsung diaplikasikan ke tanaman (Yeremia, 2016)

4. Pelatihan pembuatan pestisida nabati dari bahan dasar tanaman yang ada di sekitar petani dan aplikasi

Tahapan yang dilakukan yaitu persiapan alat dan bahan yang akan digunakan kemudian dialnjutkan dengan proses pembuatan pestisida pertama mencacah daun nimba sebanyak $8 \mathrm{~kg}$, lengkuas $6 \mathrm{~kg}$ dan serai $6 \mathrm{~kg}$ menggunakan parang. Kedua semua bahan yang telah Kegiatan pelatihan yang telah dilaksanakan adalah sebagai berikut:
5. Pelatihan pembuatan AD/ART kelompok tani alam subur.

Pelaksanaan kegiatan ini dilaksanakan dengan cara membuat AD/ART kelompok tani alam subur sesuai format yang berlaku dan aturanaturan yang ada di dalamnya secara hukum dan menghasilkan AD/ART kelompok yang telah disahkan.

6. Pelatihan pengenalan hama dan penyakit pada tanaman serta teknik pengendalian secara terpadu.

Kegiatan pelatihan ini dilakukan secara langsung di kebun petani yaitu melakukan pengamatan gejala kerusakan tanaman petsai yng terserang hama dan penyakit serta upaya pengendalian dengan melihat populasi hama dan penyakit di lapangan dan dilakukan secara mekanik dengan mengambil tanaman yang terserang serta musuh alami yang ada di pertanaman

\section{Evaluasi Program}

Evaluasi yang dilaksanakan dalam mengukur pengetahuan dan keterampilan anggota kelompok tani alam subur dalam pengelolaan pupuk dan pestisida organik yang suadah berlangsung di desa mereka, dilakukan dengan menyebarkan pertanyaan melalui pre test dan post test. Hasil pre dan post test untuk pengetahuan dan keterampilan dapat dilihat pada Grafik 1. dan 2
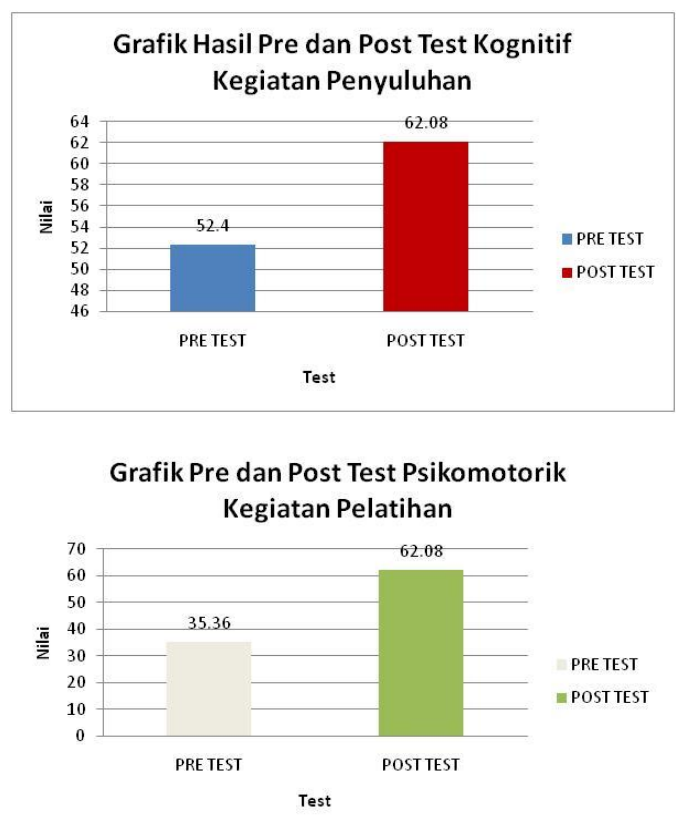
Hasil pada Grafik 1. menunjukkan bahwa nilai pre-test terhadap pengetahuan petani di kelompok tani alam subur sebesar 52,4\% dan setelah kegiatan pemberdayaan yang dilakukan mengalami peningkatan sebesar $62,08 \%$. Sedangkan untuk pelatihan nilai pre test sebesar $35,36 \%$ dan nilai post test sebesar $62,08 \%$. Ini menunjukkan bahwa pelaksanaan kegiatan ini meningkatkan pengetahuan petani kelompok alam subur dari yang tidak paham tentang pupuk organik dan pestisida nabati, tidak mampu membedakan antara hama dan penyakit, serta penguatan dalam pengelolaan kelompok serta pengenalan hama dan penyakit pada tanaman.

\section{KESIMPULAN}

Kesimpulan dari pelaksanaan kegiatan PKM ini adalah:

a. Pembuatan pupuk organik dan pestisida organik berbahan dasar tanaman lokal yang ada di sekitar petani telah dilakukan oleh kelompok tani alam subur sehingga dapat memenuhi kebutuhan pupuk dan pestisida untuk budidaya tanaman kubis dan sawi putih

b. Kelompok tani alam subur telah membuat AD/ART kelompok sesuai aturan yang berlaku dan akan diterapkan dalam pengelolaan kelompok tani

c. Petani kelompok tani alam subur telah menghasilkan produk sayur organik dan dipasarkan di Pasar Nduaria

d. Petani kelompok tani alam subur dapat melakukan tindakan pengendalian hama secara terpadu tanpa tergantung pada pestisida sintetik.

e. Kelompok tani Alam Subur diharapkan dapat menjadi pemasok pupuk dan pestisida organik di Desa Nduaria dan seluruh Desa di Kabupaten Ende.

\section{UCAPAN TERIMA KASIH}

Penulis mengucapkan terima kasih kepada DPRM Kemenristekdikti yang telah membiayai seluruh kegiatan pengabdian (SK Direktur Jenderal Penguatan Riset dan Pengembangan Kementrian Riset Teknologi dan Perguruan Tinggi Republik Indonesia No.3/E/KPT/2018 tentang Penerimaan Pendanaan Penelitian di Perguruan Tinggi tahun anggaran 2018 untuk Universitas Flores).

\section{REFERENSI}

Adriyani, R. (2006) 'Usaha Pengendalian Pencemaran Lingkungan Akibat Penggunaan Pestisida Pertanian', Kesehatan Lingkungan, 3(1), pp. 95-106. Available at: https://www.researchgate.net/profile/Retno_Ad riyani/publication/315569412_Control_of_Envi ronmental_Pollution_caused_by_Pesticide_in Agricultural_Process/links/58 d4880292851c44 d44165e6/Control-of-Environmental-Pollutioncaused-by-Pesticide-in-AgriculturalProcess.pdf.

Emiria, F. and Purwandari, H. (2014) 'Pengembangan Pertanian Organik di Kelompok Tani Madya, Desa Kebonagung, Kabupaten Bantul, Daerah Istimewa Yogyakarta', Jurnal Penyuluhan, 10(2). doi: 10.25015/penyuluhan.v10i2.9919.

Fadholi, H. (1981) Bahan Bacaan Pengantar Ekonomi Pertanian. Bogor: Fakultas Politeknik Pertanian Bogor.

Islamiyati, R. (2014) 'Nilai Nutrisi Campuran Feses Sapi dan Beberapa Level Ampas Kelapa Yang Difermentasi Dengan EM4', Buletin Nutrisi dan Makanan Ternak, 10`(1), pp. 41-46. Available at:

http://journal.unhas.ac.id/index.php/bnmt/articl e/view/913.

Marpaung, A. E. (2017) 'Pemanfaatan Jenis dan Dosis Pupuk Organik Cair (POC) untuk Meningkatkan Pertumbuhan Dan Hasil Sayuran Kubis', Jurnal Agroteknosains, 01(02), pp. 117123. Available at: http://www.portaluniversitasquality.ac.id:5388/ ojssystem/index.php/AGROTEKNOSAINS/arti cle/view/39.

Palupi, N. P. (2015) 'Ragam Larutan Mikroorganisme Lokal Sebagai Dekomposter Rumput Gajah (Pennisetum purpureum)', Ziraa'ah, 40(2), pp. 123-128. Available at: https://media.neliti.com/media/publications/223 926-ragam-larutan-mikroorganisme-lokalsebag.pdf.

Pu'u, Y. M. S. W. and Charly, M. (2018) 'Ragam Tanaman In Situ Sebagai Pupuk Organik di Kecamatan Detusoko dan Kelimutu Kabupaten Ende', Bioindustri, 1(1), pp. 27-34. Available at: http://www.universitastrilogi.ac.id/journal/ks/index.php/jbi/article/dow nload/91/78.

Yeremia, E. (2016) Pengaruh Konsentrasi Mikroorganisme Lokal (MOL) dari Rebung Bambu Terhadap Pertumbuhan Tanaman Sawi Caisim (Brassica junsea L.). Sanata Dharma. 